University of Nebraska - Lincoln

DigitalCommons@University of Nebraska - Lincoln

Publications, Agencies and Staff of the U.S.

Department of Commerce

U.S. Department of Commerce

1989

\title{
Estimates of Macroinvertebrate Biomass in Lake Michigan
}

Thomas F. Nalepa

National Oceanic and Atmospheric Administration, thomas.nalepa@noaa.gov

Follow this and additional works at: https://digitalcommons.unl.edu/usdeptcommercepub

Part of the Environmental Sciences Commons

Nalepa, Thomas F., "Estimates of Macroinvertebrate Biomass in Lake Michigan" (1989). Publications, Agencies and Staff of the U.S. Department of Commerce. 388.

https://digitalcommons.unl.edu/usdeptcommercepub/388

This Article is brought to you for free and open access by the U.S. Department of Commerce at DigitalCommons@University of Nebraska - Lincoln. It has been accepted for inclusion in Publications, Agencies and Staff of the U.S. Department of Commerce by an authorized administrator of DigitalCommons@University of Nebraska - Lincoln. 


\title{
ESTIMATES OF MACROINVERTEBRATE BIOMASS IN LAKE MICHIGAN
}

\author{
Thomas F. Nalepa \\ Great Lakes Environmental Research Laboratory \\ National Oceanic and Atmospheric Administration \\ 2205 Commonwealth Blvd. \\ Ann Arbor, Michigan 48105
}

\begin{abstract}
To obtain updated, more accurate estimates of macroinvertebrate standing stocks in Lake Michigan, benthic biomass (ash-free dry weight) was determined at 40 stations in the southern end of the lake in 1980 and 1981. Biomass generally increased as sampling depth increased from 16 to $30 \mathrm{~m}$, peaked at depths of 30-40 m, and then declined at depths greater than $40 \mathrm{~m}$. Mean total biomass at the 16-30 m, 31-50 m, 51-90, and $>90 \mathrm{~m}$ depth intervals was 4.9, 7.8, 4.2, and $1.9 \mathrm{~g} \mathrm{~m}^{-2}$, respectively. Oligochaetes (46\%) and Pontoporeia hoyi (44\%) accounted for most of the biomass at depths shallower than $30 \mathrm{~m}$, but $\mathrm{P}$. hoyi was the dominant form (65\%) at depths greater than $30 \mathrm{~m}$. Differences in total biomass between years and seasons (spring, summer, fall) were not significant, but year $\times$ season interaction was significant at depths greater than $30 \mathrm{~m}$. Mean biomass in the profundal of southern Lake Michigan $(>90 \mathrm{~m}$ ) was over twice that found in the profundal of either Lakes Superior, Huron, or Ontario.

ADDITIONAL INDEX WORDS: Standing stocks, macrobenthos, benthic fauna.
\end{abstract}

\section{INTRODUCTION}

In the Great Lakes, as in other lake systems, benthic populations represent a major trophic link between primary producers and fish. These organisms feed on detrital material settled from the water column and, in turn, are eaten by most species of fish. Using data from a variety of lake systems including the Great Lakes, recent studies have used empirical models to establish relationships between macroinvertebrate biomass and fish standing stocks and yield (Matuszek 1978, Hanson and Leggett 1982), and between macroinvertebrate biomass and variables associated with water column productivity or trophic status (Hanson and Peters 1984, Rasmussen and Kalff 1987).

As discussed by Cook and Johnson (1974), estimates of macroinvertebrate biomass should be made routinely in the Great Lakes. Biomass measurements provide a common basis for comparing benthic productivity both between and within different lakes (Alley and Powers 1970, Johnson 1974), and are useful in estimating the flow of materials through the benthic system (Gardner et al. 1985, Flint 1986). Lake-wide estimates of macroinvertebrate biomass have been made for Lake Superior (Cook 1975) and Lake Huron
(Shrivastava 1974), while more site-specific estimates have been made for Lake Ontario (Johnson and Brinkhurst 1971, Johannsson et al. 1985). Alley and Powers (1970) provided lake-wide estimates for Lake Michigan (and all the other Great Lakes except Lake Ontario); however, unlike the estimates of the other investigators, their biomass values were derived from formalin-preserved organisms. These values, although suitable for Alley and Powers' purposes in comparing the different lakes, are likely lower than actual values since formalin extracts organic matter from organisms over time (Howmiller 1972, Johnson and Brinkhurst 1971). Other, more accurate biomass estimates for Lake Michigan have been limited to a specific area (Nalepa and Quigley 1983) and/or limited to a specific taxa (Pontoporeia hoyi) (Lubner 1979, Winnell and White 1984).

In examining long-term trends of macroinvertebrate abundances over a broad area in Lake Michigan (Nalepa 1987), biomass estimates were obtained for each of the major benthic groups at each of the stations sampled. This paper presents a summary of those estimates and compares them to estimates from the other Great Lakes. 


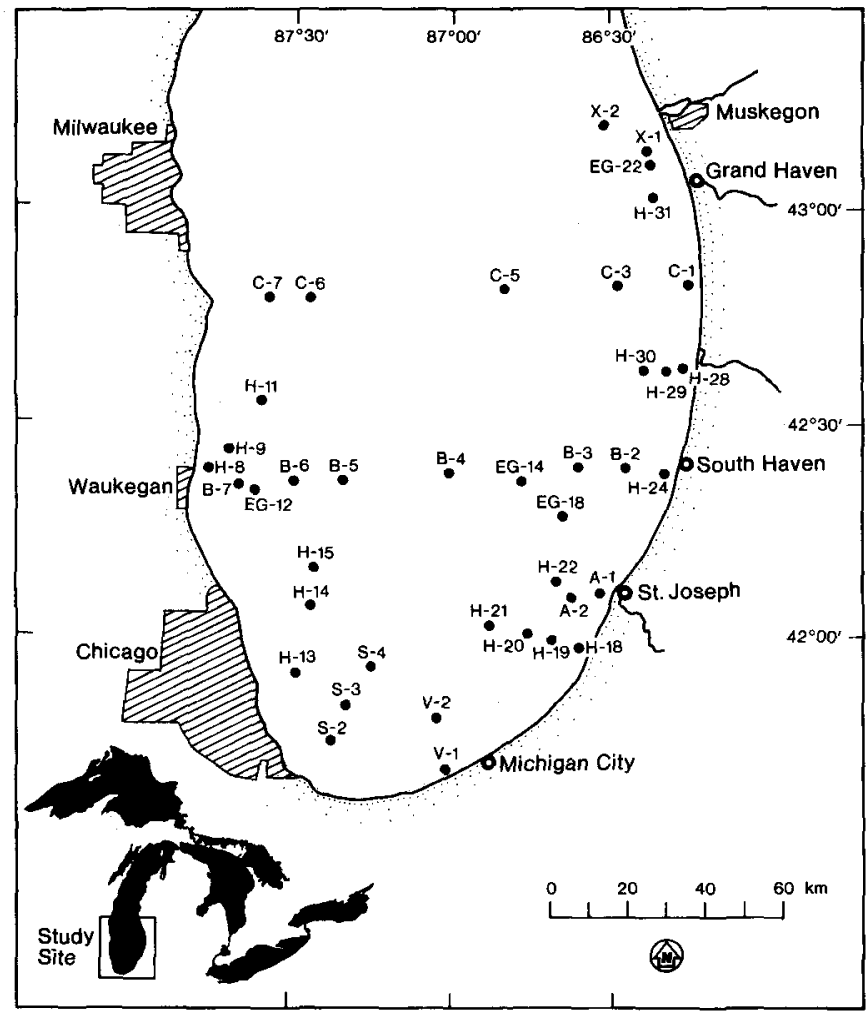

FIG. 1. Location of 40 sampling stations in Lake Michigan, 1980, 1981.

\section{METHODS}

Samples were taken at 40 stations in southern Lake Michigan (Fig. 1) in late May/early June (spring), July (summer), and September (fall) in both 1980 and 1981. The exact location and depth of each of the stations is given in Nalepa et al. (1985). Three replicates were taken with a Ponar grab at each station on each sampling date. The samples were washed into an elutriation device similar to the one described by Powers and Robertson (1965); our device was fitted with a Nitex sleeve having 0.5 mm openings. The organisms retained were immediately preserved in $10 \%$ formalin containing rose bengal stain.

All organisms in the residue were picked, counted, and sorted into major taxonomic groups (Pontoporeia hoyi, oligochaetes, sphaeriids, chironomids, and others). In some samples, the number of organisms was extremely large so only a randomly chosen portion (one eighth to one half) of the residue was picked. The number of organisms actually counted was then multiplied by the appropriate factor to obtain the total.
Biomass (ash-free dry weight $=$ AFDW) for Pontoporeia, oligochaetes, and chironomids was obtained from length-weight relationships. The length-weight relationships for Pontoporeia and oligochaetes were determined from freshly-killed individuals collected from representative stations on most sampling dates. For Pontoporeia, the length of each individual (rostrum to telson) was measured to the nearest $0.1 \mathrm{~mm}$ after straightening with forceps, dried at $60^{\circ} \mathrm{C}$ for $48 \mathrm{~h}$, and then weighed on a Cahn electrobalance. AFDW was obtained by reweighing the specimens after ashing at $550^{\circ} \mathrm{C}$ for $1 \mathrm{~h}$. The length-weight relationship for Pontoporeia was: ln AFDW (mg) $=-5.7053+$ 3.3064 ln length $(\mathrm{mm})$. Lengths of oligochaetes and oligochaete fragments were determined by placing the specimens on slides and then projecting the image onto a sheet of paper with a microscope drawing tube. Lengths were traced and then measured with a planimeter. Organisms were dried and ashed as described for Pontoporeia. The relationship between length and AFDW for oligochaetes was: AFDW $(\mathrm{mg})=0.3421 \times$ length $(\mathrm{cm})$. The AFDW of chironomids was determined from the length-weight regressions given by Nalepa and Quigley (1980). AFDW was assumed to be $90 \%$ of dry weight (Johnson and Brinkhurst 1971).

To determine the biomass of Pontoporeia in each of the samples, individuals were proportionally split with a Folsom plankton splitter and 75-100 specimens were measured and placed into seven size categories from 1.5 to $9.5 \mathrm{~mm}$. The number in each category was multiplied by the corresponding length-weight conversion and the total summed for the sample. Oligochaetes were also split proportionally and at least 75-100 individuals were placed in Amman's lactophenol and warmed for $2 \mathrm{~h}$ at $60^{\circ} \mathrm{C}$. The cleared specimens were mounted on slides (in glycerine) and traced as noted previously. Species were identified using the keys and descriptions of Brinkhurst and Jamieson (1971), Hiltunen and Klemm (1980), and Stimpson et al. (1982). Oliogachaete fragments were placed into the most probable family based on setae characteristics. Each of the traced images were labeled by taxa and lengths were measured with a planimeter. Thus, total lengths were obtained for each species (or family type in the case of fragments) in each of the samples. Total lengths were converted to AFDW using the pre-determined conversion factor. The use of the length-weight conversion factor is based on the finding the preservation does not alter length (Erman and Erman 1975). 


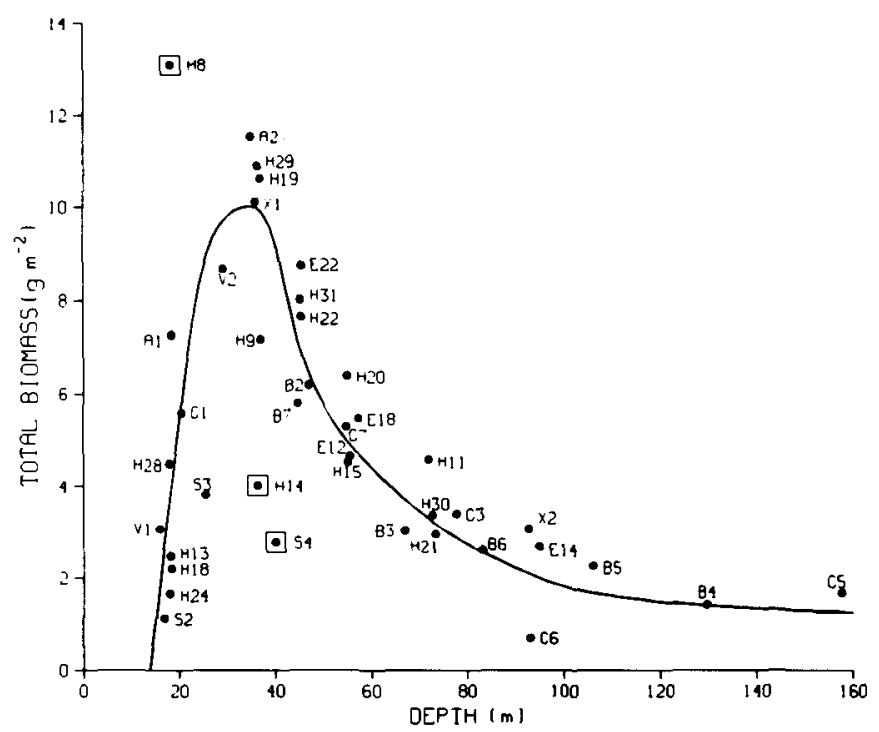

FIG. 2. Relationship between mean biomass ( $\mathrm{g}$ AFDW $\mathrm{m}^{-2}$ ) and sampling depth at each of the $\mathbf{4 0}$ stations. Line fitted by eye excluding the three stations inside the squares (stations $\mathrm{H}-8, \mathrm{H}-14$, and $\mathrm{S}-4$ ). See text for explanation of variation in these three stations.

AFDW for the other taxa found in the samples (sphaeriids, gastropods, tricopterans, and isopods) was obtained directly by drying and ashing all the specimens in a given sample. Sphaeriidae do not lose weight when preserved (Johnson and Brinkhurst 1971), but the other taxa may, so their weights were likely underestimated. However, these taxa accounted for only a small fraction of the total biomass in any given sample.

\section{RESULTS AND DISCUSSION}

At most of the stations, mean total biomass increased as sampling depth increased from 16 to $30 \mathrm{~m}$, reached a peak at $30-40 \mathrm{~m}$, and then declined at depths greater than $40 \mathrm{~m}$ (Fig. 2). These depth-related changes correspond to changes in abundances in response to shifts in physical features of the benthic habitat as depth increases (Mozley and Winnell 1975). At shallow depths above the thermocline $(<30 \mathrm{~m})$, wide fluctuations in bottom temperatures and unstable substrates keep benthic standing stocks suppressed. As depth increases, temperatures fluctutate less and the sediments are less influenced by storms and currents; also, suspended particles from the shallower regions begin to settle, providing increased food resources for the benthos. At depths just below the thermocline (30-40 m), standing stocks are at a maximum. As depth increases further, a greater proportion of potential food is mineralized in the water column before it settles to the bottom and standing stocks decline. Exceptions to this depthrelated trend occurred at stations $\mathrm{H}-8, \mathrm{H}-14$, and S-4. At station H-8, which was located at $20 \mathrm{~m}$ depth just off Waukegan, mean biomass was much higher than the biomass at other stations of similar depth. This was a result of the high abundance and biomass of tubificid oligochaetes at this station $\left(33,000 \mathrm{~m}^{-2} ; 8.7 \mathrm{~g} \mathrm{~m}^{-2}\right)$, reflecting more enriched conditions. The latter two stations were located between $25-40 \mathrm{~m}$ in the southwestern end of the lake, where the dominant substrate was gravel or coarse sand with little silt. Abundances of Pontoporeia were lower at these stations than at other stations of similar depth (Nalepa et al. 1985). This species prefers sediments with a grain size of less than $0.5 \mathrm{~mm}$ (Marzolf 1965) and reaches greatest abundances in silty sands (Mozley and Howmiller 1977). The substrate at the other stations in this depth range consisted of silt or silt-sand mixtures.

Taxonomic composition of biomass at each of four depth intervals (16-30 m, 31-50 m, 51-90 m, and $>90 \mathrm{~m}$ ) is given in Table 1 . At depths greater than $30 \mathrm{~m}$, Pontoporeia was the dominant form, accounting for $65 \%$ of total biomass. However, at the $16-30 \mathrm{~m}$ interval, Pontoporeia accounted for only $44 \%$ of the total, while oligochaetes accounted for $46 \%$. Pontoporeia is not as abundant in the shallow, nearshore zone since this glaciomarine relict does best in the uniformly colder temperatures of depths below the thermocline (Mozley and Winnell 1975). On the other hand, the proportion of tubificid oligochaetes was highest in the 16-30 $\mathrm{m}$ interval, which likely reflected the enriched nature of the nearshore zone. In southern Lake Michigan, nutrient concentrations, phytoplankton productivity, and phytoplankton biomass are several times greater in nearshore waters than in offshore waters (Schelske 1977). Also, benthic communities in the nearshore are dominated by species characteristic of eutrophic or mesotrophic waters (Winnell and White 1985, Lauritsen et al. 1985). In enriched areas, tubificids increase to a greater extent than other benthic groups and eventually become the dominant form (Milbrink 1983).

Temporal variation in total biomass was examined by comparing differences between years and seasons for each depth interval using ANOVA. Significant differences $(P<.05)$ between the 2 years 
TABLE 1. Mean biomass ( $\mathrm{g} A F D W \mathrm{~m}^{-2}$ ) of major benthic taxa in each of four depth intervals in southern Lake Michigan, 1980 and 1981. Number in parentheses gives the percentage of the total for each major group in each interval. Total biomass also includes values of minor taxa not shown.

\begin{tabular}{|c|c|c|c|c|c|c|c|c|}
\hline \multirow[b]{2}{*}{ Taxa } & \multicolumn{8}{|c|}{ Depth Interval (m) } \\
\hline & $16-30$ & & $31-50$ & & $51-90$ & & $>90$ & \\
\hline Pontoporeia hoyi & 2.14 & $(43.9)$ & 4.70 & $(60.0)$ & 3.00 & (71.3) & 1.36 & $(71.2)$ \\
\hline Total Oligochaeta & 2.23 & (45.7) & 2.90 & $(37.0)$ & 1.13 & (26.8) & 0.52 & $(27.2)$ \\
\hline Stylodrilus heringianus & 0.89 & & 2.17 & & 0.70 & & 0.46 & \\
\hline Tubificidae & 1.30 & & 0.71 & & 0.40 & & 0.06 & \\
\hline Sphaeriidae & 0.37 & (7.6) & 0.22 & $(2.8)$ & 0.05 & $(1.2)$ & 0.02 & $(1.0)$ \\
\hline Chironomidae & 0.08 & (1.6) & 0.02 & $(0.3)$ & 0.02 & $(0.5)$ & 0.01 & $(0.5)$ \\
\hline Total Biomass & 4.88 & & 7.83 & & 4.21 & & 1.91 & \\
\hline
\end{tabular}

and the three seasons were not apparent for any of the depth intervals. However, a significant year $x$ season interaction was apparent for the three deepest depth categories. In 1980, biomass was highest in the spring and then declined; in 1981, biomass in the spring was lower than in the spring of 1980 , but higher in the summer and fall (Table 2).

Of the 40 stations sampled in 1980 and 1981, 25 were located at or in close proximity to stations sampled in the 1960s by Alley and Powers (1970) (for exact stations and further details see Nalepa 1987). The mean biomass at these stations in this survey was $4.4 \mathrm{~g} \mathrm{~m}^{-2}$ compared to $3.4 \mathrm{~g} \mathrm{~m}^{-2}$ in the earlier survey. Besides a general increase in macroinvertebrate abundances during the time period between the two surveys (Nalepa 1987), the 1960s biomass estimates were likely too low because, as noted earlier, they were derived from

TABLE 2. Mean total biomass ( $\mathrm{g} A \mathrm{FDW} \mathrm{m}^{-2}$ ) at each of four depth intervals by season and year. Number in parentheses represents the number of stations in each depth interval.

\begin{tabular}{lcccc}
\hline & \multicolumn{4}{c}{ Depth Interval $(\mathrm{m})$} \\
\cline { 2 - 5 } Season, Year & $\begin{array}{c}16-30 \\
(11)\end{array}$ & $\begin{array}{c}31-50 \\
(12)\end{array}$ & $\begin{array}{c}51-90 \\
(11)\end{array}$ & $\begin{array}{c}>90 \\
(6)\end{array}$ \\
\hline Spring & & & & \\
$\quad 1980$ & 5.20 & 9.87 & 5.22 & 2.85 \\
$\quad 1981$ & 3.78 & 6.93 & 3.88 & 1.48 \\
Summer & & & & \\
$\quad 1980$ & 4.43 & 7.54 & 3.82 & 1.70 \\
$\quad 1981$ & 5.63 & 7.98 & 4.44 & 2.30 \\
Fall & & & & \\
1980 & 5.02 & 6.72 & 3.66 & 1.54 \\
1981 & 5.26 & 8.04 & 4.23 & 1.87 \\
\hline
\end{tabular}

formalin-preserved specimens. Correction factors can conceivably be applied to make the two data sets more comparable and thus determine exactly the extent by which benthic biomass increased between the 1960s and 1980-81. However, weight loss in preserved specimens varies by benthic group (Johnson and Brinkhurst 1971), and the proportional contribution of the different groups was not determined in the earlier survey. At any rate, the relative increase in total biomass between the two surveys was most apparent at the shallower depths. The median of the increase factor (the increase factor is the ratio of total biomass in this survey to total biomass in the previous survey calculated for each station; Nalepa 1987) for stations in the 16$30 \mathrm{~m}, 31-50 \mathrm{~m}, 51-90 \mathrm{~m}$, and $>90 \mathrm{~m}$ intervals was $2.4,1.2,1.1$, and 0.8 respectively.

Other estimates of biomass in Lake Michigan have been mostly restricted to the dominant form, Pontoporeia hoyi (Table 3). In general, biomass estimates in this study were comparable to these previous values (at similar depths) except when compared to the values reported by Lubner (1979). At depths greater than $90 \mathrm{~m}$, Lubner's values were twice as great as those found in this study. His stations were located on the western side of the lake which tends to be more productive than comparable areas on the eastern side because of a higher frequency of upwelling (Alley and Mozley 1975, Lubner 1979). Mean abundance and mean weight per individual of Pontoporeia at the Lubner stations $\left(5,520 \mathrm{~m}^{-2} ; 0.67 \mathrm{mg} ; \mathrm{n}=3\right)$ were higher than at stations of similar depth in this study $\left(4,170 \mathrm{~m}^{-2} ; 0.48 \mathrm{mg} ; \mathrm{n}=10\right)$. In this study, a comparison of Pontoporeia biomass at stations in the depth range of $50-100 \mathrm{~m}$ on the western side of the lake $(n=7)$ to the biomass at stations on the 
TABLE 3. Previous estimates of macroinvertebrate biomass $^{\prime}\left(\mathrm{g} A F D W \mathrm{~m}^{-2}\right)$ in Lake Michigan.

\begin{tabular}{|c|c|c|c|}
\hline $\begin{array}{l}\text { Depth } \\
(\mathrm{m})\end{array}$ & Total & $\begin{array}{c}\text { Pontoporeia } \\
\text { hoyi }\end{array}$ & Source \\
\hline 11 & 2.85 & 0.72 & Nalepa and Quigley (1983) \\
\hline 15 & - & 0.77 & Winnell and White (1984) \\
\hline 17 & 6.35 & 3.51 & Nalepa and Quigley (1983) \\
\hline 23 & 8.86 & 6.08 & Nalepa and Quigley (1983) \\
\hline 42 & - & 4.74 & Winnell and White (1984) \\
\hline 65 & - & 3.89 & Lubner (1979) \\
\hline 90 & - & 2.78 & Lubner (1979) \\
\hline 115 & - & 2.63 & Lubner (1979) \\
\hline
\end{tabular}

Values of Winnell and White (1984) and Lubner (1979) were converted to AFDW by assuming an ash content of $15 \%$. All values for Pontoporeia hoyi were obtained from length-weight relationships. Nalepa and Quigley (1983) sampled using diver's cores while the other investigators used a Ponar grab.

eastern side $(n=8)$ indicated a slightly higher, but nonsignificant, mean biomass of Pontoporeia on the western side $\left(2.7 \pm 0.5 \mathrm{~g} \mathrm{~m}^{-2}\right.$ on western side; $2.5 \pm 0.3 \mathrm{~g} \mathrm{~m}^{-2}$ on eastern side).

Recent estimates of benthic biomass in each of the Great Lakes except Lake Erie are given in Table 4. Only values from profundal areas are presented because biomass is less variable at profundal depth $(>90 \mathrm{~m})$ than at shallower depths (see Fig. 2) and, further, biomass in the profundal generally provides a more accurate assessment of lake productivity since this is where most sedimented material eventually accumulates (Saether 1980, Rasmussen and Kalff 1987). As indicated in Table 4 , benthic standing stocks is the profundal of Lake Michigan are at least 2.5 times greater than in the profundal of the three other lakes.

Of the many variables that may influence ben- thic biomass in a given water body, two of the most important are mean depth and water column productivity; biomass is inversely related to the former and directly related to the latter (Rawson 1953, Alley and Powers 1970, Rasmussen and Kalff 1987). Yet differences in water depth and water column productivity cannot entirely explain the higher biomass values found in Lake Michigan. Even when depths are generally comparable, standing stocks in Lake Michigan are far greater than in Lakes Superior, Huron, or Ontario (Table 4) and, although primary production and chlorophyll concentrations in Lake Michigan are higher than in Lakes Huron and Superior, they are lower than in Lake Ontario (Vollenweider et al. 1974). Exceptionally high benthic standing stocks in Lake Michigan have been attributed simply to the naturally higher fertility of its drainage basin (Cook and Johnson 1974, Mozley and Howmiller 1977). Another reason may be related to a more direct relationship between primary production and the benthos in Lake Michigan. The magnitude of the spring diatom bloom in Lake Michigan exceeds that found in the other lakes (G. Fahnenstiel, NOAA Great Lakes Environmental Research Laboratory, Ann Arbor, personal communication). Because of the cold temperatures and lack of zooplankton grazers in the spring, a large portion of the diatom bloom settles intact directly to the bottom (Scavia and Fahnenstiel 1987). This material apparently is readily eaten by the benthos, as evidenced by an increase in lipid levels of several groups in the spring (Gardner et al. 1985). Thus, higher macroinvertbrate standing stocks in Lake Michigan (when compared to standing stocks in the other lakes) may be a result of greater inputs of a high quality food resource. To test this hypothesis, the seasonal flux and nutritional value of set-

TABLE 4. Mean macroinvertebrate biomass $\left(\mathrm{g} A F D W \mathrm{~m}^{-2}\right)$ in the profundal $(>90 \mathrm{~m})$ of Lakes Superior, Huron, Ontario, and Michigan.

\begin{tabular}{lcccccl}
\hline \hline Lake & $\begin{array}{c}\text { Number of } \\
\text { Stations }\end{array}$ & $\begin{array}{c}\text { Mean Depth } \\
\text { of Stations } \\
(\mathbf{m})\end{array}$ & $\begin{array}{c}\text { Total } \\
\text { Biomass }\end{array}$ & $\begin{array}{c}\text { Pontoporeia } \\
\text { hoyi }\end{array}$ & Oligochaeta & \multicolumn{1}{c}{ Source } \\
\hline Superior & 59 & 156 & 0.05 & - & - & Cook (1975) \\
Huron & 13 & 149 & 0.60 & 0.50 & 0.06 & Shrivastava (1974) \\
Ontario & 2 & 115 & 0.69 & 0.57 & 0.17 & Johannsson et al. (1985) \\
Michigan & 6 & 113 & 1.97 & 1.36 & 0.52 & This study \\
\hline
\end{tabular}

'Estimates for Lake Huron were converted from dry weights by assuming an ash content of $15 \%$. All investigators used a Ponar grab. 
tling epilimnetic particles should be examined in each of the lakes along with the corresponding seasonal changes in the lipid levels of the major benthic groups.

Accurate estimates of benthic biomass are needed to obtain realistic assessments of materials flow through benthic systems (i.e., Gardner $e t$ al. 1985, Flint 1986). Knowing biomass and bottom water temperatures, at least a first-order estimate of benthic production can be realized (Johnson and Brinkhurst 1971). Also relevant is the taxonomic composition of biomass, for not all benthic groups consume and assimilate energy to the same extent, and not all groups are utilized equally by fish. The values presented provide an updated, bygroup assessment of benthic standing stocks in southern Lake Michigan. Of course, while these values are suitable for examining relative trends in space or time and for comparing relative productivity between different lakes (provided sampling procedures and methods of biomass estimation are similar), absolute values may be higher by a factor of 1.7 since the Ponar grab tends to underestimate biomass by this amount (Nalepa et al. 1988).

\section{ACKNOWLEDGMENTS}

I thank M. Quigley for his field support and B. Burns, J. Grimes, and D. Morse of the R/V Shenehon for their help and cooperation during field operations. I also thank $L$. Herche for advice on statistical analysis and W. Gardner, M. Quigley, A. Beeton, and D. Schloesser for suggestions on the manuscript. GLERL contribution no. 611 .

\section{REFERENCES}

Alley, W. P., and Mozley, S. C. 1975. Seasonal abundance and spatial distribution of Lake Michigan macrobenthos, 1964-67. Great Lakes Research Division Spec. Publ. 54. University of Michigan, Ann Arbor, MI. , and Powers, C. F. 1970. Dry weight of the macrobenthos as an indicator of eutrophication of the Great Lakes. In Proc. 13th Conf. Great Lakes Res., pp. 595-600. Internat. Assoc. Great Lakes Res.

Brinkhurst, R. O., and Jamieson, B. G. M. 1971. Aquatic oligochaeta of the world. Downsview, Ont.: Universtiy of Toronto Press.

Cook, D. G. 1975. A preliminary report of the benthic macroinvertebrates of Lake Ontario. J. Fish. Res. Board Can. Tech. Rep. 449. and Johnson, M. G. 1974. Benthic macroinvertebrates of the St. Lawrence Great Lakes. J. Fish. Res. Board Can. 31:763-782.

Erman, D. C. and Erman, N. A. 1975. Macroinvertebrate composition and production in some Sierra Nevada minerotrophic peatlands. Ecology 56: 591-603.

Flint, R. W. 1986. Hypothesized carbon flow in the deepwater Lake Ontario food web. J. Great Lakes Res. 12:344-354.

Gardner, W. S., Nalepa, T. F., Frez, W. A., Cichocki, E. A., and Landrum, P. F. 1985. Seasonal patterns in lipid content of Lake Michigan macroinvertebrates. Can. J. Fish. Aquat. Sci. 42:1827-1832.

Hanson, J. M., and Leggett, W. C. 1982. Empirical prediction of fish biomass and yield. Can. J. Fish. Aquat. Sci. 39:257-263.

, and Peters, R. H. 1984. Empirical predictions of crustacean zooplankton and profundal macrobenthos biomass in lakes. Can. J. Fish. Aquat. Sci. 41:439-445.

Hiltunen, J. K., and Klemm, D. J. 1980. A guide to the Naididae (Annelida: Clitellata: Oligochaeta) of North America. U. S. Environmental Protection Agency, Ecological Research Series, EPA-600/4-80031 .

Howmiller, R. P. 1972. Effects of preservatives on weights of some common macrobenthic invertebrates. Trans. Am. Fish. Soc. 101:743-746.

Johannsson, O. E., Dermott, R. M., Feldkamp, R., and Moore, J. E. 1985. Lake Ontario Long Term Biological Monitoring Program, 1981, 1982, Data Base. Can. Data Rept. Fish. Aquat. Sci. No. 552.

Johnson, M. G. 1974. Production and productivity. In R. O. Brinkhurst (ed), The Benthos of Lakes, p. 46-64. London: Macmillan Press.

, and Brinkhurst, R. O. 1971. Production of benthic invertebrates of Bay of Quinte and Lake Ontario. J. Fish. Res. Board of Can. 28:1699-1714.

Lauritsen, D. D., Mozley, S. C., and White, D. S. 1985. Distribution of oligochaetes in Lake Michigan and comments on their use as indices of pollution. $J$. Great Lakes Res. 11:67-76.

Lubner, J. F. 1979. Population dynamics and production of the relict amphipod Pontoporeia hoyi at several Lake Michigan stations. Ph.D. thesis, University of Wisconsin, Milwaukee, WI.

Marzolf, G. R. 1965. Substrate relations of the burrowing amphipod Pontoporeia affinis in Lake Michigan. Ecology 46:579-592.

Matuszek, J. E. 1978. Empirical prediction of fish yields of large North American lakes. Trans. Am. Fish Soc. 107:385-394.

Milbrink, G. 1983. An improved environmental index based on the relative abundance of oligochaete species. Hydrobiologia 102:89-97. 
Mozley, S. C., and Howmiller, R. P. 1977. Environmental status of the Lake Michigan region: zoobenthos of Lake Michigan. Argonne National Lab. Rep. No. ANL/ES-40. Vol. 6. U. S. Energy Research and Development Administration. , and Winnell, M. H. 1975. Macrozoobenthic species assemblages of southeastern Lake Michigan, U.S.A. Verh. Internat. Verein. Limnol. 19: 922-931

Nalepa, T. F. 1987. Long-term changes in the macrobenthos of southern Lake Michigan. Can. J. Fish. Aquat. Sci. 44:515-524.

, and Quigley, M. A. 1980. The macro- and meiobenthos of southeastern Lake Michigan near the mouth of the Grand River, 1976-77. NOAA Data Rep. ERL GLERL-17. Great Lakes Environmental Research Laboratory, Ann Arbor, MI. , and Quigley, M. A. 1983. Abundance and biomass of the meiobenthos in nearshore Lake Michigan with comparisons to the macrobenthos. J. Great Lake Res. 9:530-547.

Quigley, M. A., Childs, K. F., Gauvin, J. M., Heatlie, T. S., Parker, M. P., and Vanover, L. 1985. Macrobenthos of southern Lake Michigan, 1980-81. NOAA Data Rep. ERL GLERL-28. Great Lakes Environmental Research Laboratory, Ann Arbor, MI.

, Quigley, M. A., and Ziegler, R. W. 1988. Sampling efficiency of the Ponar grab in two different benthic environments. J. Great Lakes Res. 14:89-93.

Powers, C. F., and Robertson, A. 1965. Some quantitative aspects of the macrobenthos of Lake Michigan. In Proc. 8th Conf. Great Lakes Res., pp.153-159. Great Lakes Res. Div. Publ. No. 13. University of Michigan, Ann Arbor, MI.
Rasmussen, J. B., and Kalff, J. 1987. Empirical models for zoobenthic biomass in lakes. Can. J. Fish. Aquat. Sci. 44:990-1001.

Rawson, D. S. 1953. The bottom fauna of Great Slave Lake. J. Fish. Res. Board Can. 25:254-283.

Saether, O. A. 1980. The influence of eutrophication of deep lake benthic invertebrate communities. Prog. Water Technol. 12:161-180.

Scavia, D., and Fahnenstiel, G. L. 1987. Dynamics of Lake Michigan phytoplankton: mechanisms controlling epilimnetic communities. J. Great Lakes Res. 13:103-120.

Schelske, C. L. 1977. Trophic status and nutrient loading for Lake Michigan. In North American project-A study of U.S. water bodies: a report for the Organization of Economic Cooperation and Development, pp. 499-536. U. S. Environmental Protection Agency, Ecological Research Series, EPA-600/3-77-086.

Shrivastava, H. N. 1974. Macrobenthos of Lake Huron. J. Fish. Res. Board Can. Tech. Rep. 449.

Stimpson, K. S., Klemm, D. J., Hiltunen, J. K. 1982. $A$ guide to the fresh water Tubificidae (Annelida: Clitellata: Oligochaeta) of North America. U. S. Environmental Protection Agency, Ecological Research Series, EPA-600/3-82-003.

Vollenweider, R. A., Munawar, M., and Stadelmann, P. 1974. A comparative review of phytoplankton and primary production in the Laurentian Great Lakes. J. Fish. Res. Board Can. 31:739-762.

Winnell, M. H., and White, D. S. 1984. Ecology of shallow and deepwater populations Pontoporeia hoyi (Smith) (Amphipoda) in Lake Michigan. Freshwat. Invertebr. Biol. 3:118-138. , and White, D. S. 1985. Trophic status of southeastern Lake Michigan based on the Chironomidae (Diptera). J. Great Lakes Res. 11:540-548. 